\title{
The angiotensin II receptors type 1 blockage affects the urinary bladder activity in hyperosmolar-induced detrusor overactivity in rats: Preliminary results
}

\author{
Kajetan Juszczak ${ }^{1,2, A-F}$, Piotr Maciukiewicz ${ }^{2, A, E, F}$ \\ ${ }^{1}$ Department of Pathophysiology, Jagiellonian University Medical College, Kraków, Poland \\ 2 Department of Urology, Memorial Rydygier Hospital, Kraków, Poland \\ A - research concept and design; $\mathrm{B}$ - collection and/or assembly of data; $\mathrm{C}$ - data analysis and interpretation; \\ $\mathrm{D}$ - writing the article; $\mathrm{E}$ - critical revision of the article; $\mathrm{F}$ - final approval of article
}

Address for correspondence

Kajetan Juszczak

E-mail:kajus13@poczta.onet.pl

Funding sources

None declared

Conflict of interest

None declared

\section{Acknowledgements}

This study was supported by grant number

K/ZDS/004609 from Jagiellonian University Collegium

Medicum, Kraków, Poland.

Received on May 9, 2015

Revised on October 7, 2015

Accepted on September 1,2016

\begin{abstract}
Background. Angiotensin II receptors play a role in the pathogenesis of urinary bladder dysfunction, especially in the case of bladder outlet obstruction. The function of these receptors in the detrusor overactivity (DO) still remains unclear.
\end{abstract}

Objectives. The study aims to investigate some of the mechanisms through which hyperosmolarity induces urinary bladder overactivity. The effect of angiotensin II receptor type 1 - AT1 (telmisartan) on urinary bladder function in physiological state and in hyperosmolar-induced D0 in rat model was explored.

Material and methods. Experiments were performed on 32 female Wistar rats. D0 was induced by hyperosmolar saline intravesical instillation. Surgical procedures and cystometry were performed under urethane anesthesia. The measurements represent the average of 5 bladder micturition cycles. We analyzed: basal pressure, threshold pressure, micturition voiding pressure, intercontraction interval, compliance, functional bladder capacity, motility index and detrusor overactivity index.

Results. Intravesical hyperosmolar saline instillation induced D0. Telmisartan diminished the severity of hyperosmolar-induced D0. We observed a statistically significant increase of intercontraction interval (55\%), functional bladder capacity (54\%), compliance (140\%). Also, a statistically significant decrease of detrusor overactivity index (18\%) and motility index (9\%) were observed. The difference of basal pressure, threshold pressure and micturition voiding pressure were not statistically significant. Moreover, telmisartan has no effect on urodynamic parameters in naïve rats.

Conclusions. Detrusor overactivity due to intravesical increased osmolarity seems to be at least partially mediated by AT1 receptors activity. On one hand, telmisartan diminished the severity of hyperosmolarinduced D0, and, on the other hand, has no effect on urodynamic parameters in naive rats.

Key words: rat, overactive bladder, telmisartan, osmolarity, cystometry

DOI

$10.17219 /$ acem $/ 64939$

Copyright

Copyright by Author(s)

This is an article distributed under the terms of the

Creative Commons Attribution Non-Commercial License

(http://creativecommons.org/licenses/by-nc-nd/4.0/) 
Urinary bladder function is regulated by the somatic and autonomic nervous system (ANS). With the exception of the cholinergic (via muscarinic receptors) and the adrenergic branch of ANS (via $\alpha$ and $\beta$ receptors), the non-cholinergic/non-adrenergic mechanisms (NCNA) play an important role in proper urine storage and voiding. A wide range of neurotransmitters of the NCNA branch of ANS (e.g. SP - substance P, CGRP - calcitonin gene related peptide, ATP - adenosine 5'-triphosphate, VIP - vasoactive intestinal polypeptide, NY - neuropeptide Y, somatostatin, bombesin, etc.) act as stimulatory or inhibitory neuromodulators of adrenergic, cholinergic as well as purinergic transmission of lower urinary tract. ${ }^{1}$ NCNA mechanisms implicated in the urethral sphincter action have been described previously. Phull et al. ${ }^{2}$ observed that the blockade of angiotensin II receptors type 1 (AT1) and type 2 (AT2) decreases urethral resistance in stress urinary incontinence rat model. Moreover, angiotensin II treatment improves urethral tone in sphincter deficiency in the rat model. On the other hand, Tanabe et $\mathrm{al}^{3}$ showed that the AT1 receptors, rather than AT2 receptors, mediate angiotensin induced smooth muscle rat urinary bladder strips contractions in in vitro studies. In the literature there is still sparse data regarding the role of the renin-angiotensin-aldosteron system in lower urinary tract function. Animal studies showed that estrogen deprivation leads to voiding dysfunction and urethral hypermobility. The main pathomechanisms for this seem to be increased angiotensin-converting enzyme (ACE) activity and up-regulation of AT1 and AT2 receptors. ${ }^{4}$ Furthermore, Cho et al. ${ }^{5}$ described the role of AT1 receptors in the development of detrusor overactivity (DO) due to bladder outlet obstruction (BOO) in a rat model. The function of AT1 receptors in DO remain unclear.

Therefore, we examined the effect of angiotensin II receptor type 1 - AT1 (Telmisartan) on urinary bladder function in the physiological state and in hyperosmolarinduced detrusor overactivity in a rat model.

\section{Material and methods}

\section{Animals}

Experiments were performed on 32 adult female Wistar rats (weight: 200-250 g). Rats were housed individually in cages. The animal room was maintained at a constant temperature $\left(23^{\circ} \mathrm{C}\right)$, humidity and a $12: 12 \mathrm{~h}$ alternating light-dark cycle. They were fed with animal food (Labofeed; Kcynia, Poland) without any restriction to water. The study has been approved by the Local Animals Ethical Committee.

\section{Experimental groups}

Thirty two animals were divided randomly into 5 groups: I (control) - healthy rats $(\mathrm{n}=12)$, II - rats with hyperosmolar induced DO $(n=6)$, III - rats with hyper- osmolar induced DO and intravesical administration of telmisartan $(n=6), I V$ - healthy rats with intravesical administration of telmisartan $(n=6), V-$ healthy rats with intravesical administration of DMSO solution used for telmisartan preparation $(n=2)$.

\section{Anesthesia}

All the surgical procedures and urodynamic studies were performed under anesthesia using intraperitoneal injection of $1.2 \mathrm{~g} / \mathrm{kg}$ urethane (Sigma-Aldrich, St. Louis, USA). ${ }^{6}$

\section{Detrusor overactivity (DO) induced by hyperosmolar intravesical stimulation}

The neural reflex transmitted by unmyelinated afferent $C$ fibers is crucial in DO development. Hyperosmolar stimuli activate these nerves via vanilloid receptors leading to increased local effector activity of $\mathrm{C}$ fibers. High concentrated urine penetrates the submucosal layers of the urinary bladder and activates capsaicin-sensitive $\mathrm{C}$ neurons and consequently, inducing neurogenic inflammation, which leads to DO. ${ }^{7}$ The water deprivation for $16 \mathrm{~h}$ is sufficient to determine urine concentrating ability of kidneys. The urine concentration tests in female rats revealed that mean urine osmolarity was $2080 \mathrm{mOsm} / \mathrm{L} .{ }^{8}$ Hypertonic saline within physiological osmolarity range induces concentrated-dependent DO. Therefore, DO was induced by a continuously intravesical infusion of hypertonic saline solution (in physiological range at $2080 \mathrm{mOsm} / \mathrm{L}$ ) at a rate of $0.046 \mathrm{~mL} / \mathrm{min} .{ }^{9}$

\section{Drugs}

Telmisartan (Sigma-Aldrich, Germany), a non-peptide AT1 angiotensin II receptor antagonist, was used in the following study. Telmisartan was dissolved in DMSO and in $0.9 \%$ saline to a final concentration of $3 \mathrm{mg} / \mathrm{kg}$ per dose. Under urethane anesthesia, the bladder was catheterized through the urethra and emptied. The telmisartan solution at $0.3 \mathrm{~mL}$ final volume was gently injected through the catheter (group III and IV) at a rate of $0.15 \mathrm{~mL} / \mathrm{min}$, and subsequently was left in contact with the urinary bladder mucosa for $15 \mathrm{~min}$. Then the bladder was emptied again and flushed out using $0.5 \mathrm{~mL} 0.9 \%$ saline at a rate of $0.15 \mathrm{~mL} / \mathrm{min} .5,10$

\section{Surgical procedure}

Bladder catheter implantation: under urethane anesthesia, the abdomen was opened through a midline incision, and the bladder end of the polyethylene catheter (o.d. $0.97 \mathrm{~mm} /$ i.d. $0.58 \mathrm{~mm}$; BALT, Poland) was passed through a $1 \mathrm{~mm}$ incision at the apex of the bladder dome and secured in place by a silk ligature 4-0, as previously described. ${ }^{10}$ 


\section{Urodynamic studies}

Cystometry was performed under urethane anesthesia after a $1 \mathrm{~h}$ recovery period from the surgical procedure. A room temperature solution was infused at a rate of $0.046 \mathrm{~mL} / \mathrm{min}$ continuously into the urinary bladder. The free end of the implanted catheter was connected via a T-stopcock to a pressure transducer (UFI, MorroBay, USA) and injection pump (Unipan340A, Poland). Cystometry was recorded using PowerLab/8SP (ADInstruments, Castle Hill, Australia) set, as previously described. ${ }^{10,11}$

\section{Experimental protocol}

All animals underwent cystometry using isoosmolar (308 mOsm/L) saline solution (group I); hyperosmolar saline solution (group II); hyperosmolar saline after telmisartan solution administration (group III); isoosmolar saline after telmisartan solution administration (group IV); and isoosmolar saline solution after DMSO solution administration. DMSO solution was composed of $0.9 \%$ saline (75\%), DMSO (25\%) (the volume participation of individual components in solvent expressed in the per cent, is provided in square brackets). The measurements, which were repeated in each animal, represent the average of 5 bladder micturition cycles, after obtaining repetitive voiding. The following cystometrogram parameters were recorded: $\mathrm{BP}$ - basal pressure $\left(\mathrm{cm} \mathrm{H}_{2} \mathrm{O}\right), \mathrm{PT}$ - threshold pressure $\left(\mathrm{cm} \mathrm{H}_{2} \mathrm{O}\right)$, MVP - micturition voiding pressure $\left(\mathrm{cm} \mathrm{H}_{2} \mathrm{O}\right)$, ICI - intercontraction interval [min.], compliance $\left(\mathrm{mL} / \mathrm{cm} \mathrm{H}_{2} \mathrm{O}\right)$,
$\mathrm{fBC}$ - functional bladder capacity [mL], MI - motility index ( $\mathrm{cm} \mathrm{H}_{2} \mathrm{O} \times \mathrm{s} / \mathrm{min}$ ) in 10-minute intervals, DI - detrusor in$\operatorname{dex}\left(\mathrm{cm} \mathrm{H}_{2} \mathrm{O} / \mathrm{mL}\right)$ (in group I and IV) and DOI - detrusor overactivity index ( $\mathrm{cm} \mathrm{H}_{2} \mathrm{O} / \mathrm{mL}$ ) (in group II and III), depicted as a quotient of the sum of amplitudes of all detrusor contractions during the filling phase and functional bladder capacity. ${ }^{11}$ The intravesical administration of DMSO solution has no significant effect on motor and sensory urinary bladder activity (group V), thus this group was excluded from further analysis.

\section{Statistical analysis}

The results are expressed as mean and standard deviation $( \pm \mathrm{SD})$. The Kruskal-Wallis test was used to compare the groups and a post hoc multiple comparison test was used for statistically significant results. Statistical significance was set at $\mathrm{p} \leq 0.05$ for all tests.

Fig. 1. Cystometry in control rats

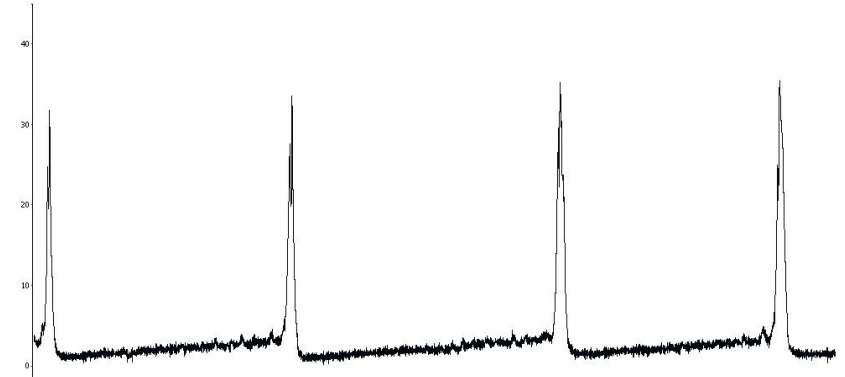

The figure shows 20-min interval - horizontal axis. Vertical axis estimates intravesical pressure of $(-5)-45 \mathrm{~cm} \mathrm{H}_{2} \mathrm{O}$ range.

Table 1. Cystometric parameters of control rats (group I), hyperosmolar-induced detrusor overactivity (group II), hyperosmolar-induced detrusor overactivity after intravesical telmisartan administration (group III), control after intravesical telmisartan administration (group IV)

\begin{tabular}{|c|c|c|c|c|c|}
\hline $\begin{array}{l}\text { Cystometric } \\
\text { parameters }\end{array}$ & $\begin{array}{l}\text { Group I } \\
\text { control }\end{array}$ & $\begin{array}{c}\text { Group II } \\
\text { hyperosmolar- } \\
\text { induced detrusor } \\
\text { overactivity }\end{array}$ & $\begin{array}{c}\text { Group III } \\
\text { hyperosmolar-induced } \\
\text { detrusor overactivity }+ \\
\text { Telmisartan }\end{array}$ & $\begin{array}{c}\text { Group IV } \\
\text { control + telmisartan }\end{array}$ & $p$-value \\
\hline $\begin{array}{l}\text { Basal pressure (BP) } \\
{\left[\mathrm{cm} \mathrm{H}_{2} \mathrm{O}\right]}\end{array}$ & $1.41 \pm 0.60$ & $3.07 \pm 0.16^{*}$ & $3.20 \pm 0.19$ & $2.45 \pm 0.79$ & *0.01 vs group I \\
\hline $\begin{array}{l}\text { Threshold pressure (PT) } \\
{\left[\mathrm{cm} \mathrm{H}_{2} \mathrm{O}\right]}\end{array}$ & $5.70 \pm 1.22$ & $6.12 \pm 0.26$ & $5.12 \pm 0.68$ & $5.40 \pm 1.08$ & ns \\
\hline $\begin{array}{l}\text { Micturition voiding pressure (MVP) } \\
{\left[\mathrm{Cm} \mathrm{H}_{2} \mathrm{O}\right]}\end{array}$ & $27.40 \pm 4.90$ & $25.90 \pm 4.90$ & $29.15 \pm 3.62$ & $30.12 \pm 2.38$ & ns \\
\hline $\begin{array}{l}\text { Intercontraction interval }(\mathrm{ICl}) \\
\text { [min] }\end{array}$ & $5.28 \pm 1.55$ & $2.59 \pm 0.26^{*}$ & $4.02 \pm 0.47^{* *}$ & $5.70 \pm 2.13$ & $\begin{array}{l}{ }^{*} 0.001 \text { vs group I } \\
{ }^{* *} 0.002 \text { vs group II }\end{array}$ \\
\hline $\begin{array}{l}\text { Compliance } \\
{\left[\mathrm{mL} / \mathrm{cm} \mathrm{H}_{2} \mathrm{O}\right]}\end{array}$ & $0.059 \pm 0.019$ & $0.040 \pm 0.008$ & $0.096 \pm 0.011^{* *}$ & $0.045 \pm 0.012$ & **0.005 vs group II \\
\hline $\begin{array}{l}\text { Functional bladder capacity (fBC) } \\
{[\mathrm{mL}]}\end{array}$ & $0.240 \pm 0.070$ & $0.120 \pm 0.012^{*}$ & $0.185 \pm 0.022^{* *}$ & $0.262 \pm 0.098$ & $\begin{array}{l}{ }^{*} 0.001 \text { vs group I } \\
{ }^{* *} 0.002 \text { vs group II }\end{array}$ \\
\hline $\begin{array}{l}\text { Detrusor index (DI) / detrusor } \\
\text { overactivity index (DOI) } \\
{\left[\mathrm{cm} \mathrm{H}_{2} \mathrm{O} / \mathrm{mL}\right]}\end{array}$ & $121.9 \pm 33.0$ & $625.8 \pm 101.4^{*}$ & $512.3 \pm 59.7^{* *}$ & $132.4 \pm 42.1$ & $\begin{array}{l}{ }^{*} 0.001 \text { vs group I } \\
{ }^{* *} 0.004 \text { vs group II }\end{array}$ \\
\hline $\begin{array}{l}\text { Motility index (MI) } \\
{\left[\mathrm{cm} \mathrm{H}_{2} \mathrm{O} \times \mathrm{s} / \mathrm{min}\right]}\end{array}$ & $185.4 \pm 45.9$ & $245.2 \pm 61.5^{*}$ & $223.7 \pm 31.7^{* *}$ & $203.7 \pm 31.0$ & $\begin{array}{l}{ }^{*} 0.009 \text { vs group I } \\
*{ }^{*} 0.005 \text { vs group II }\end{array}$ \\
\hline
\end{tabular}

* $p<0.05$ vs group l; ** $p<0.05$ vs group II. 


\section{Results}

\section{The effect of intravesical hyperosmolar stimulation on urinary bladder activity in normal rats (group I and II)}

Intravesical infusion of hyperosmolar $(2080 \mathrm{mOsm} / \mathrm{L})$ saline solution induced DO. All hyperosmolar DO rats did not exhibit macroscopically signs of bladder inflammation, i.e. redness, oedema as well as wall thickening, mucosal erosions, ulcerations, petechial hemorrhages on the serosal surface. Cystometric evaluations revealed a significant decrease of intercontraction intervals (104\%) and functional bladder capacity (100\%). Additionally,

Fig. 2. Cystometry in rats with hyperosmolar-induced DO

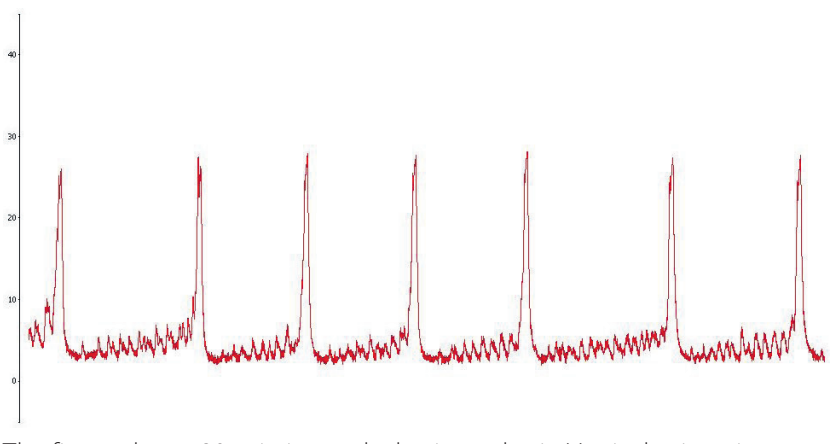

The figure shows 20-min interval - horizontal axis. Vertical axis estimates intravesical pressure of $(-5)-45 \mathrm{~cm} \mathrm{H}_{2} \mathrm{O}$ range.

Fig. 3. Cystometry in rats with hyperosmolar-induced DO after intravesical telmisartan administration

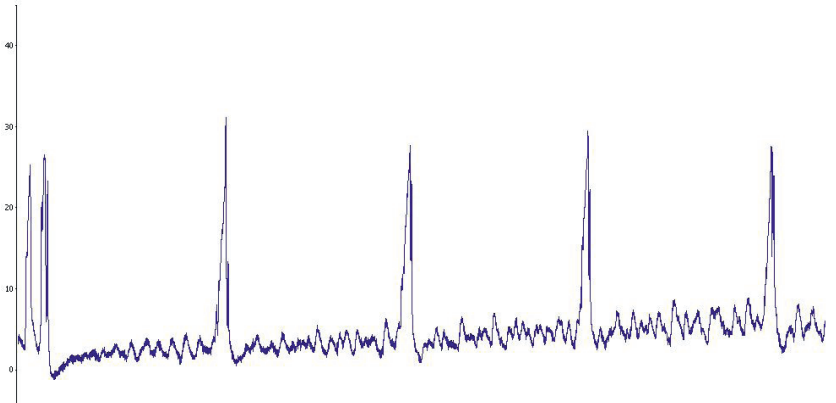

The figure shows 20-min interval - horizontal axis. Vertical axis estimates intravesical pressure of $(-5)-45 \mathrm{~cm} \mathrm{H}_{2} \mathrm{O}$ range.

Fig. 4. Cystometry in control rats after intravesical telmisartan administration

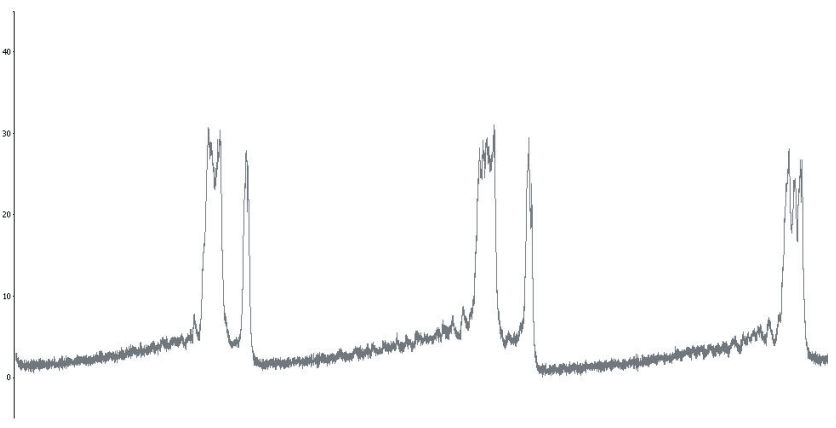

The figure shows 20-min interval - horizontal axis. Vertical axis estimates intravesical pressure of $(-5)-45 \mathrm{~cm} \mathrm{H}_{2} \mathrm{O}$ range. an increase of basal pressure (118\%), detrusor activity (413\%) and motility index (33\%) were observed (Table 1, Fig. 1, 2). No statistical differences of threshold, micturition voiding pressure and compliance were obtained.

\section{The effect of intravesical administration of telmisartan on urinary bladder activity in rats with hyperosmolar-induced DO and in healthy rats (group III and IV)}

The intravesical blockage of angiotensin II receptor type 1 by telmisartan diminished the severity of hyperosmolar-induced detrusor overactivity (Table 1, Fig. 3). In comparison with hyperosmolar-induced DO rats we observed a statistically significant increase of intercontraction interval (55\%), functional bladder capacity (54\%), compliance (140\%). Also, a statistically significant decrease of detrusor overactivity index (18\%) and motility index (9\%) were observed. The difference of basal, threshold and micturition voiding pressure were not statistically significant. On the other hand, the intravesical blockage of angiotensin II receptor type 1 by telmisartan has no significant impact on urinary bladder function in naïve rats (Table 1, Fig. 4).

\section{Discussion}

Clinical evidence of hypertensive patients with lower urinary tract symptoms (LUTS) treated with different types of antihypertensive drugs shows that patients taking angiotensin II receptor blockers (ARBs) report a reduction of LUTS severity as compared to others on angiotensin-converting enzyme inhibitors or calcium channel blockers. ${ }^{12}$ This fact suggests that angiotensin II receptors play a role in urinary bladder function. The pathophysiological role of angiotensin II in the cardio-vascular system was established in detail. Angiotensin II regulates the vascular tone and smooth muscle cells growth, as well as stimulating collagen production via AT1 receptors. ${ }^{13}$ The data about its function in lower urinary tracts is still sparse. The function of AT1 receptors in detrusor overactivity development remains unclear. So far there is no research on the importance of angiotensin II in bladder dysfunction in humans. Few repots exist showing that the modulation of renin-angiotensin-aldosteron activity affects the lower urinary tracts function. Ito et al. ${ }^{12}$ indicate that the International Prostate Symptom Score (IPSS) describing lower urinary tract symptoms (LUTS) is lower in patients with arterial hypertension treated with angiotensin II receptor blockers. On the other hand, Elliott et al. ${ }^{14}$ described that angiotensin converting enzyme (ACE) inhibitors and ARBs are associated with the reduction of urge urinary incontinence especially in men. There are several animal models establishing the role of angiotensin II mainly in the course of bladder out- 
let obstruction, hypertensive rats or estrogen-deficient ovariectomized animals. Our experiment revealed that the intravesical blockage of angiotensin II receptor type 1 by telmisartan diminished the severity of hyperosmolarinduced detrusor overactivity (DO). Therefore, besides the well-studied pathomechanisms of DO, a AT1-dependent pathway seems to be at least partially involved in the pathogenesis of DO. Angiotensin II - dependent pathway seems to be involved in urinary bladder motor activity. Both angiotensin I and II induced a potent contraction of the human detrusor muscle. It is probable that angiotensin I is converted to angiotensin II by ACE in the detrusor muscle, and angiotensin II subsequently mediates detrusor contraction. ${ }^{15}$ Angiotensin II participates in detrusor muscle cells growth and collagen production within urinary bladder wall. Cheng et al. ${ }^{16}$ postulated some pathomechanisms responsible for detrusor motor activity and collagen changes in urinary bladder dysfunctions. An interesting study of Shimizu et al. ${ }^{17}$ on spontaneously hypertensive rats showed that ACE inhibitors ameliorates urodynamic parameters and urinary bladder oxidative injury as compared to normal rats. Thus, telmisartan also may restore proper urinary bladder blood flow and consequently prevent from oxidative stress induction and bladder damage leading to OAB/DO. The current pharmacotherapy and intravesical botulinum toxin administration are well developed. ${ }^{18-20}$ However, such therapy is not fully beneficial. Therefore, new treatment options are required. Taking into account all of the above mentioned facts the modulation of angiotensin II - dependent pathway may have an impact on more sufficient treatment of $\mathrm{OAB} / \mathrm{DO}$.

\section{Conclusions}

Detrusor overactivity, resulting from intravesical increased osmolarity, seems to be at least partially mediated by angiotensin II type 1 (AT1) receptors activity. Therefore, angiotensin II receptors dependent pathways may become a potential target for urinary bladder dysfunction treatment using angiotensin II receptors blockers, especially in patients with co-existing arterial hypertension.

\section{References}

1. Hoyle $\mathrm{CH}$. Non-adrenergic, non-cholinergic control of the urinary bladder. World J Urol. 1994;12:233-244.

2. Phull H, Salkini M, Escobar C, Purves T, Comiter CV. The role of angiotensin II in stress urinary incontinence: A rat model. Neurourol Urodyn. 2007;26:81-88.

3. Tanabe N, Ueno A, Tsujimoto G. Angiotensin II receptors in the rat urinary bladder smooth muscle: Type 1 subtype receptors mediate contractile responses. J Urol. 1993;150:1056-1059.

4. Ramos-Filho AC, A Faria J, Calmasini FB, et al. The renin-angiotensin system plays a major role in voiding dysfunction of ovariectomized rats. Life Sci. 2013;93:820-829.

5. Cho ST, Park EZ, Kim JC. Effect of angiotensin II receptor antagonist telmisartan on detrusor overactivity in rats with bladder outlet obstruction. Urology. 2012;80(5):1163.e1-7.
6. Dinis P, Churrua A, Avelino A, Cruz F. Intravesical resiniferatoxin decreases spinal c-fos expression and increases bladder volume to reflex micturition in rats with chronic inflamed urinary bladders. BJU Int. 2004;94:153-157.

7. Garland A, Jordan JE, Necheles J, et al. Hypertonicity, but not hypothermia, elicits substance $P$ release from rat $C$-fiber neurons in primary culture. J Clin Invest. 1995;95:2359-2366.

8. Kulick LJ, Clemons DJ, Hall R, Koch MA. Refinement of the urine concentration test in rats. Contemp Top Lab Anim Sci. 2005;44:46-49.

9. Juszczak K, Ziomber A, Wyczółkowski M, Thor PJ. Hyperosmolarity alters the micturition: The comparison of urinary bladder motor activity in hyperosmolar and cyclophosphamide-induced models of overactive bladder. Can J Physiol Pharmacol. 2010;88:899-906.

10. Juszczak K, Ziomber A, Wyczółkowski M, Thor PJ. Urodynamic effects of the bladder C-fiber afferent activity modulation in chronic overactive bladder model rats. J Physiol Pharmacol. 2009;60,:85-91.

11. Juszczak K, Krolczyk G, Filipek M, Dobrowolski ZF, Thor PJ. Animal models of overactive bladder: Cyclophosphamide (CYP)-induced cystitis in rats. Folia Med Cracov. 2007;48:113-123.

12. Ito $H$, Taga M, Tsuchiyama $K$, Akino H, Yokoyama O. IPSS is lower in hypertensive patients treated with angiotensin-II receptor blocker: Posthoc analyses of a lower urinary tract symptoms population. Neurourol Urodyn. 2013;32:70-74.

13. Ford CM, Li S, Pickering JG. Angiotensin II stimulates collagen synthesis in human vascular smooth muscle cells. Involvement of the AT(1) receptor, transforming growth factor-beta, and tyrosine phosphorylation. Arterioscler Thromb Vasc Biol. 1999;19:1843-1851.

14. Elliott CS, Comiter CV. The effect of angiotensin inhibition on urinary incontinence: Data from the National Health and Nutrition Examination Survey (2001-2008). Neurourol Urodyn. 2014;33:1178-1181.

15. Saito $M$, Kondo $A$, Kato T, Miyake K. Response of the human urinary bladder to angiotensins: A comparison between neurogenic and control bladders. J Urol. 1993;149:408-411.

16. Cheng EY, Decker RS, Lee C. Role of angiotensin II in bladder smooth muscle growth and function. Adv Exp Med Biol. 1999;462:183-191.

17. Shimizu $S$, Saito $M$, Oiwa $H$, et al. Olmesartan ameliorates urinary dysfunction in the spontaneously hypertensive rat via recovering bladder blood flow and decreasing oxidative stress. Neurourol Urodyn. 2014;33:350-357.

18. Kosilov K, Loparev S, Iwanowskaya M, Kosilova L. Effectiveness of combined high-dosed trospium and solifenacin depending on severity of $O A B$ symptoms in elderly men and women under cyclic therapy. Cent European J Urol. 2014;67:43-48.

19. Malki M, Mangera A, Reid S, Inman R, Chapple C. What is the feasibility of switching to $200 \mathrm{IU}$ onabotulinumtoxin $A$ in patients with detrusor overactivity who have previously received 300IU? Cent European J Urol. 2014;67:35-40.

20. Persu C, Braschi E, Lavelle J. A reviev of prospective clinical trials for neurogenic bladder: Pharmaceuticals. Cent European J Urol. 2014;67:264-269. 